\title{
BELANJA MODAL MEMEDIASI PENGARUH PENDAPATAN DAERAH TERHADAP PERTUMBUHAN EKONOMI DAERAH OTONOMI KHUSUS
}

\author{
Langgeng Prayitno Utomo ${ }^{1}$ \\ Nur Fadjrih Asyik ${ }^{2}$ \\ Suwardi Bambang Hermanto ${ }^{3}$ \\ 1,2,3 SekolahTinggi Ilmu Ekonomi Indonesia (STIESIA), Surabaya, Jawa Timur, Indonesia \\ email: lan99en9.pu36@gmail.com
}

\begin{abstract}
ABSTRAK
Pemerintah dan masyarakat mengelola sumber daya dan membentuk pola kemitraan serta saling bekerjasama untuk menciptakan pembangunan dalam memicu perkembangan kegiatan ekonomi daerah. Tujuan penelitian menguji pengaruh pendapatan daerah terhadap pertumbuhan ekonomi daerah otonomi khusus yang dimediasi oleh belanja modal. Sampel penelitian adalah realisasi anggaran pendapatan dan belanja daerah (RAPBD) kabupaten dan kota pada daerah otonomi khusus provinsi Papua tahun 2011-2015. Teknik penyamplingan menggunakan purposive sampling dan diperoleh 120 sampel. Alat analisis yang digunakan Structural Equation Modeling (SEM). Hasil pengujian menunjukan bahwa, besarnya jumlah pendapatan daerah berpengaruh positif terhadap pertumbuhan ekonomi daerah otonomi khusus dan belanja modal. Selain itu, penambahan besaran alokasi pada belanja modal berpengaruh positif terhadap pertumbuhan ekonomi.Belanja modal mampu memediasi pendapatan daerah terhadap pertumbuhan ekonomi daerah otonomi khusus. Implikasi penelitian diharapkan dapat digunakan untuk mempertimbangkan komponen belanja yang dianggap mampu untuk mendorong perekonomian daerah atau secara langsung bersinggungan dengan kegiatan ekonomi masyarakat sehingga mampu menunjang produktivitas dan mobilisasi masyarakat di daerah.
\end{abstract}

Kata kunci: Belanja modal, pendapatan daerah, pertumbuhan ekonomi

\section{CAPITAL SHOPPING PROVIDES EFFECT OF REVERSAL REVENUES ON ECONOMIC GROWTHSPECIAL AUTONOMY REGIONS}

\begin{abstract}
The purpose of this study is to examine the effect of regional income on the economic growth of special autonomous regions mediated by capital expenditure. The sample of this study is the realization of regional income and expenditure budget of districts and municipalities in the special autonomous region of Papua province for the year of 2011-2015. By using purposive sampling technique, this study obtained 120 data observation report. The test is done by Structural Equation Modeling (SEM) technique. The test results indicate that the amount of regional revenue has a positive effect on economic growth, besides the regional revenue also has a positive effect on capital expenditure, then the addition of allocation amount on capital expenditure has a positive effect on economic growth. Capital expenditure is able to partially mediate the regional income on economic growth in the form of partial or partial mediation.
\end{abstract}

Keywords: Capital expenditure, regional income, economic growth DOI: https://doi.org/10.24843/JIAB.2017.v12.i01.p06

\section{PENDAHULUAN}

Pertumbuhan ekonomi menjadi salah satu tujuan penting bagi pemerintah. Pertumbuhan ekonomi yang baik akan mampu meningkatkan kesejahteraan masyarakat, menciptakan lapangan kerja serta meningkatkan pelayanan publik. Untuk mencapai hal tersebut, tentunya diperlukan investasi cukup besar terutama dalam menyediakan infrastruktur yang memadai, baik kualitas maupun kuantitas.
Pembangunan infrastruktur yang baik akan mampu mendorong mobilitas barang dan jasa, meningkatkan akses pelayanan publik dan mengurangi disparitas sehingga mampu mendorong pertumbuhan ekonomi. (Dunca, 2007).

Pembangunan ekonomi daerah adalah suatu tindakan dimana pemerintah daerah dan seluruh lapisan masyarakat mengelola sumber daya yang ada 
dan membentuk suatu pola kemitraan dan saling berkerjasama untuk menciptakan pembangunan dan merangsang perkembangan kegiatan ekonomi di daerah tersebut (Dunca, 2007). Otonomi daerah merupakan pola kemitraan yang dapat dilakukan, di era desentralisasi fiskal seperti saat ini. Pemerintah daerah diberikan pelimpahan tugas, fungsi dan wewenang pemerintah pusat melalui otonomi daerah untuk mengatur dan mengurus daerah secara mandiri sesuai dengan kebutuhan dan aspirasi masyarakat daerah dengan harapan mampu mendorong meningkatnya perekonomian di daerah. (Firman, 2009). Otonomi daerah diarahkan untuk mewujudkan alokasi sumber daya nasional yang efisien melalui hubungan keuangan pusat dan daerah yang transparan dan akuntabel telah diatur dalam undangundang nomor 33 tahun 2004 tentang perimbangan keuangan antara pemerintah pusat dan daerah melalui instrumen pendapatan daerah yang terdiri atas Dana Alokasi Umum (DAU), Dana Alokasi Khusus (DAK), dan Dana Bagi Hasil (DBH) yang bersumber dari APBN, sebagai pendamping Pendapatan Asli Daerah (PAD) yang peroleh dari kemampuan daerah dalam mengelola potensi dan sumber daya yang ada di daerah.

Otonomi daerah yang belaku umum dalam desentralisasi fiskal, terdapat pula otonomi khusus dimana daerah yang menjalankan desentralisasi asimetris ini diperlakukan berbeda dengan daerah lain. Otonomi khusus merupakan perhatian pemerintah pusat bagi daerah tertinggal, tujuannya adalah untuk mempercepat pembangunan bagi daerah tertinggal agar mampu sejajar dengan daerah lain di Indonesia. Salah satunya adalah provinsi Papua sesuai dengan amanat undang-undang nomor 21 Tahun 2001 tentang otonomi khusus bagi provinsi Papua yang mencakup, pertama pembagian otorisasi dan urusan antara pemerintah pusat dengan pemerintah daerah serta pelaksanaan otoritas kekhususan dalam bingkai NKRI. Kedua, pengakuan dan penghormatan hakhak dasar masyarakat adat Papua melalui pengembangan kemampuan secara strategis serta mendasar, dan ketiga menciptakan governance yang baik.

Pemerintah Papua memperoleh dana otonomi khusus (DOK), dana alokasi umum (DAU), Dana Alokasi khusus (DAK) dan dana bagi hasil (DBH) untuk melaksanakan pembangunan. Hal tersebut berdampak terhadap pendapatan daerah Papua meningkat dua kali lipat, sehingga anggaran pendapatan APBD Papua yang cukup besar. Hal ini semestinya dapat digunakan untuk pembangunan infrastruktur daerah secara maksimal melalui belanja modal guna meningkatkan mobilitas, mempermudah akses serta membuka keterisolasian sehingga mampu mendorong pertumbuhan ekonomi masyarakat daerah (Agustinus, 2013).

Beberapa penelitian sebelumnya tentang pengalokasian pendapatan daerah terhadap pertumbuhan ekonomi jika di mediasi oleh belanja modal, telah dilakukan antara lain oleh Uhise (2013), tentang pengaruh pendapatan daerah terhadap pertumbuhan ekonomi Sulawesi Utara dengan belanja modal sebagai variabel intervening hasil dari penelitian ini menunjukan bahwa pendapatan daerah secara langsung tidak berpengaruh terhadap pertumbuhan ekonomi, selanjutnya pendapatan daerah berpengaruh terhadap belanja modal dan lebih lanjut pendapatan daerah berpengaruh terhadap pertumbuhan ekonomi melalui belanja modal, sehingga dapat disimpulkan belanja modal memediasi pengaruh dana pendapatan daerah terhadap pertumbuhan ekonomi penelitian ini di dukung oleh (Maryati, 2010).

Hasil penelitian lain menujukan hal yang berbeda, seperti penelitian oleh Hendriwiyato (2013) melakukan penelitian tentang pengaruh pendapatan daerah terhadap pertumbuhan ekonomi dengan belanja modal sebagai variabel mediasi hasil penelitian ini menujukan PAD, DAU, DAK, dan DBH secara langsung berpengaruh terhadap pertumbuhan ekonomi, sedangkan hasil pengujian lebih lanjut menujukkan bahwa PAD, DAU, DAK, dan DBH melalui belanja modal tidak berpengaruh terhadap pertumbuhan ekonomi artinya belanja modal bukan variabel mediasi pendapatan daerah terhadap pertumbuhan ekonomi.

Adiputra dkk.,(2015) melakukan penelitian tentang pengaruh pendapatan daerah terhadap kualitas pembangunan manusia dengan alokasi belanja modal sebagai variabel intervening. Hasil penelitian ini menunjukan, pendapatan daerah tidak berpengaruh terhadap kualitas pembangunan manusia secara langsung, sedangkan pengaruh secara tidak langsung melalui belanja modal pendapatan daerah berpengaruh terhadap kualitas pembangunan manusia hal ini menujukan bahwa belanja modal memediasi pendapatan daerah terhadap kualitas pembangunan manusia.

Sumardjoko (2014) melakukan penelitian pengaruh pendapatan dana otonomi khusus terhadap indeks pembangunan manusia Papua dan Papua Barat dengan belanja modal sebagai intervening, hasil dari penelitian tersebut menujukan dana otonomi berpengaruh signifikan positif terhadap belanja modal, dan dana otonomi khusus secara langsung 
berpengaruh terhadap indeks pembangunan manusia, selanjutnya belanja modal berperan sebagai variabel intervening dalam memberi pengaruh dana otonomi khusus terhadap indeks pembangunan manusia.

Penelitian ini dilakukan pada daerah yang menjalankan otonomi khusus yaitu provinsi Papua. Isu otonomi khusus Papua menjadi menarik untuk diteliti lebih lanjut karena provinsi Papua adalah daerah pertama dan telah menjalankan kebijakan otonomi khusus selama lima belas tahun dalam bingkai NKRI. Pelaksanaan otonomi khusus ini akan berlaku untuk jangka waktu dua puluh lima tahun. Pengelolaannya harus dilakukan dengan baik dan tepat sasaran. Kedua, besarnya pendapatan APBD Pemerintah Papua, dalam otonomi khusus yang diatur dalam undang-undang pemerintah daerah Papua. Penerima dana otonomi khusus (DOK) juga menerima porsi pendapatan revenue sharing sumber daya alam 55 persen, minyak bumi dan gas alam sebesar 40 persen, serta pendapatan atas pajak bumi bangunan (PBB) sebesar 90 persen. Pembagian ini tentunya berbeda apabila dibandingkan daerah lainnya dengan besarnya pendapatan yang diterima oleh provinsi Papua melalui otonomi khusus. Pendapatan yang diterima diharapkan mampu meningkatkan kesejahteraan dan taraf hidup masyarakat Papua. Kenyataannya otonomi khusus yang telah bergulir hampir lima belas tahun belum mampu meningkatkan kesejahteraan dan taraf hidup masyarakat Papua sesuai dengan yang di harapan. Daerah Papua masih menjadi daerah yang tertinggal dibandingkan dengan daerah lain di Indonesia. Data BPS di tahun 2014 sejumlah 40,78 persen. penduduk Papua masih hidup dalam status rumah tangga miskin (RTM). Rata-rata pertumbuhan ekonomi dengan indikator PDRB hanya $\pm 4,0$ persen yang sebagian besar ditopang sektor pertambangan, masih rendah jika dibandingkan daerah lain yang berkisar $5-7$ persen.

Fiscal Federalism Theory merupakan teori yang dibangun oleh Hayek dalam Bahl (1999) .Teori ini menyatakan pertumbuhan ekonomi dapat dicapai melalui desentralisasi fiskal atau pendelegasian wewenang dari pemerintah pusat kepada pemerintah daerah untuk mengatur daerahnya sendiri atau dikenal dengan otonomi. Desentralisasi fiskal merupakan proses pendistribusian anggaran dari pemerintahan yang lebih tinggi kepada pemerintahan yang lebih rendah. Desentralisasi ini mendukung tugas dan fungsi pemerintahan serta pelayanan publik sesuai dengan kewenangan yang dilimpahkan kepada pemerintah yang lebih rendah (Lee, 2013). Desentralisasi fiskal berkaitan dengan pembagian tugas dan tanggung jawab antar tingkat pemerintahan.
Transfer antar tingkat pemerintahan, penguatan sistem pendapatan daerah dan perumusan sistem pelayanan publik di daerah serta distribusi pembangunan dan pendapatan yang merata. Peranan pemerintah sebagaimana termuat dalam fiscal federalism theory memiliki tiga fungsi utama yaitu stabilisasi makroekonomi, distribusi pendapatan dan alokasi sumber pendapatan (Fjeldstad, 2001).

Pelaksanaan desentralisasi fiskal harus memperhatikan prinsip money should follow function yang mengindikasikan bahwa setiap pelimpahan wewenang pemerintahan akan membawa implikasi pendanaan yang diperlukan untuk melaksanakan kewenangan tersebut (Bahl, 1999). Pemerintah daerah dituntut untuk dapat lebih mandiri dalam melaksanakan pembangunan baik dari sisi perencanaan maupun pelaksanaannya berdasarkan kaidah-kaidah otonomi daerah. Prinsip money follow function, pendapatan harus diiringi dengan diskresi yang lebih luas untuk pembelanjaannya sesuai dengan kebutuhan dan prioritas daerah. Kondisi ini akan menciptakan local government spending yang benar-benar bermanfaat dan menjadi stimulus fiskal bagi pertumbuhan ekonomi daerah dalam rangka mewujudkan kesejahteraan masyarakat (Stine, 2003). Keberhasilan desentralisasi fiskal mewujudkan kesejahteraan masyarakat salah satunya bergantung pada bagaimana pemerintah lokal mengalokasikan belanjanya pada kegiatan yang berfokus pada kebutuhan masyarakat dengan menekankan quality spending. Dengan delegasi kewenangan, proses penganggaran melibatkan banyak partisipan sehingga menciptakan efektifitas (Hagen, 2002).

Pasal 1 angka 1 UU No. 21 tahun 2001 tentang otonomi khusus bagi Provinsi Papua, menyatakan bahwa otonomi khusus merupakan kewenangan khusus yang diakui dan diberikan kepada provinsi untuk mengatur dan mengurus kepentingan masyarakat setempat menurut prakarsa sendiri berdasarkan aspirasi masyarakat. Otonomi berarti hak yang diberikan kepada masyarakat etnis atau penduduk satu wilayah bertenis khusus tertentu, yang tidak memiliki kedaulatan (politik) sendiri untuk melaksanakan suatu yuridiksi eksekutif (McGibbon, 2004). Tiga hal yang perlu diperhatikan, yaitu (1) Definisi tersebut mencakup dua bentuk, antara lain otonomi wilayah (territorial autonomy) dan otonomi non wilayah (non territorial autonomy, (2) Bentuk otonomi asimetris dan otonomi berlaku umum. (3) Definisi tersebut dikembangkan dari perspektif kelompok etnis atau wilayah yang didasarkan atas etnis, yang karenanya kemudian perlu memiliki 
otonomi sendiri. Berdasarkan pemaparan tersebut maka dirumuskan hipotesis berikut.

$\mathrm{H}_{1}$ : Pengaruh pendapatan daerah terhadap pertumbuhan ekonomi.

Pendapatan daerah sebagai sumber pembiayaan daerah diharapkan mampu menciptakan sejumlah aktivitas ekonomi baru dalam masyarakat (Barro, 1991). Dengan meningkatnya aktivitas ekonomi pada masyarakat, akan terjadi peningkatan jumlah output barang dan jasa yang diikuti pula dengan meningkatnya jumlah uang beredar dari segi pembelanjaan yang dilakukan oleh pemerintah (Krueger, 1990). Hal tersebut akan meningkatkan pendapatan nilai PDRB dan tingkat kesejahteraan masyarakat.

Penelitian Hendriwiyanto (2013) menunjukkan bahwa Pendapatan daerah berpengaruh positif terhadap pertumbuhan ekonomi. Daerah lebih leluasa dalam mengatur prioritas pembangunan di daerahnya dan mampu mendorong peningkatan ekonomi di daerah. Dimang (2011), Laimeheriwa (2013) Gunantara dan Dwirandra (2014) menyimpulkan bahwa dengan meningkatnya pendapatan daerah maka daerah menjadi lebih mampu dalam memberikan fasilitas pelayanan publik yang lebih baik untuk masyarakat lokal. Berdasarkan penjelasan maka hipotesis penelitian adalah.

$\mathrm{H}_{2}$ : Pendapatan Daerah berpengaruh positif terhadap belanja modal.

Semakin banyak Pendapatan suatu daerah maka semakin besar pula alokasi belanja modalnya. Pendapatan daerah dapat meningkatkan investasi belanja modal pemerintah daerah sehingga kualitas pelayanan publik semakin baik. Penelitian oleh Kusnandar dan Siswantoro (2011) menyatakan bahwa pendapatan daerah berpengaruh positif terhadap alokasi belanja modal.Penelitian Laimeheriwa (2013) pendapatan daerah yang tinggi akan mempengaruhi pembangunan di daerah yang direalisasikan dalam bentuk pengadaan fasilitas, infrastruktur, dan sarana prasarana yang ditujukan untuk kepentingan publik melalui belanja modal. Berdasarkan pemaparan tersebut hipotesis penelitian adalah:

$\mathrm{H}_{3}$ : Belanja modal berpengaruh positif terhadap pertumbuhan ekonomi.

Pengeluaran pemerintah dalam bentuk alokasi belanja modal didasarkan pada kebutuhan sarana dan prasarana publik. Fasilitas publik bertujuan untuk kelancaran pelaksanaan tugas pemerintahan berupa peralatan dan mesin, gedung dan bangunan, jalan, irigasi dan jaringan, dan aset tetap lainnya. Peningkatan belanja modal diharapkan menjadi faktor pendorong timbulnya berbagai investasi baru di daerah dalam mengoptimalkan pemanfaatan berbagai sumber daya untuk kegiatan produksi sehingga pada akhirnya dapat meningkatkan pertumbuhan ekonomi daerah.

Penelitian Sodik (2007), Hendriwijanto (2013) dan Dimang, (2011) menyimpulkan adanya pengaruh positif yang signifikan dari pengeluaran pemerintah baik pengeluaran pembangunan maupun pengeluaran rutin terhadap pertumbuhan ekonomi regional dikarenakan pengeluaran pembangunan sangat diperlukan oleh suatu daerah untuk tumbuh dan berkembang sesuai dengan kemampuannya sendiri. Berdasarkan penjelasan tersebut maka hipotesis penelitian adalah:

$\mathrm{H}_{4}$ : Belanja modal memediasi pengaruh pendapatan daerah terhadap pertumbuhan ekonomi.

Pertumbuhan ekonomi regional menjadi salah satu agenda penting setelah otonomi daerah. Cara pemerintah daerah adalah melalui optimalisasi pendapatan daerah, akan tetapi kenaikan pendapatan daerah tidak serta merta meningkatkan pertumbuhan ekonomi tanpa diikuti anggaran belanja yang efektif dan efisien dalam bentuk kegiatan-kegiatan produktif yang mengarahkan pada pembangunan ekonomi berkelanjutan.

Penelitian Uhise (2013) menunjukan bahwa dana alokasi umum secara langsung tidak berpengaruh terhadap pertumbuhan ekonomi, lebih lanjut dana alokasi umum berpengaruh terhadap pertumbuhan ekonomi melalui belanja modal, sehingga dapat disimpulkan belanja modal memediasi pengaruh dana alokasi umum terhadap pertumbuhan ekonomi.

\section{METODE PENELITIAN}

Penelitian ini merupakan penelitian deskriptif dengan jenis penelitian kuantitatif. Peneltian ini bertujuan untuk mengetahui pengaruh variabel eksogenus pendapatan pada daerah terhadap variabel endogenus pertumbuhan ekonomi dengan melibatkan variabel intervening yaitu belanja modal. Objek penelitian adalah kumpulan elemen yang terkait dengan laporan keuangan pemerintah daerah dalam APBD kabupaten/kota di Provinsi Papua. Jangka waktu penelitian selama lima tahun dari 20112015 dengan mengunakan data sekunder. Metode penentuan sampel menggunakan metode purposive sampling diperoleh 29 kabupaten/kota dengan 120 data observasi.

UU No. 33 tahun 2004 tentang Perimbangan Keuangan Antara Pemerintah Pusat dan Pemerintah 
Daerah yang dimaksud dengan PAD adalah pendapatan daerah yang bersumber dari hasil pajak daerah, hasil retribusi daerah, hasil pengelolaan kekayaan daerah yang dipisahkan, dan PAD yang sah, yang bertujuan untuk memberikan kewenangan kepada daerah dalam menggali pendanaan dalam pelaksanaan otonomi daerah sebagai perwujudan asas desentralisasi. Dalam Undang-undang Nomor 32 Tahun 2004 Pendapatan Asli Daerah diukur dengan rumus :

$\mathrm{PAD}=$ Pendapatan Pajak Daerah $(\mathrm{PPD})+$ Pendapatan Retribusi Daerah (PRD) + Pendapatan Hasil Pengelolaan Kekayaan Daerah yang Dipisahkan (HPKDD) + Lain-lain PAD yang sah

Data diperoleh dari realisasi APBD pada pos pendapatan daerah. Dalam penelitian Adiputra dkk. (2015) dan Hendriwijanto (2013) variabel ini diukur dengan presentasi PAD terhadap total pendapatan daerah ditulis dalam rumus :

$\mathrm{PAD}=\frac{\text { Pendapatan Asli Daerah }(\mathrm{PAD})}{\text { Total PenerimaanDaerah }} \times 100 \% \ldots$

Undang-Undang No. 27 tahun 2014 tentang Perimbangan Keuangan Antara Pemerintah Pusat dan Pemerintah Daerah yang dimaksud dengan Dana Alokasi Umum adalah dana yang bersumber dari pendapatan APBN yang dialokasikan dengan tujuan pemerataan kemampuan keuangan antar daerah untuk mendanai kebutuhan daerah dalam rangka pelaksanaan desentralisasi. Hasil Perhitungan DAU untuk masing-masing daerah ditetapkan dengan keputusan presiden berdasarkan usulan dewan pertimbangan otonomi daerah. Dalam Undangundang No. 27 tahun 2014 DAU baik untuk daerah provinsi maupun untuk daerah Kabupaten/Kota dalam penelitian Adiputra et al (2015) dan Hendriwijanto (2013) variabel ini diukur dengan presentasi DAU terhadap total pendapatan daerah ditulis dalam rumus:

DAU $=$ Alokasi Dasar (AD) + Celah Fiskal (CF)

Dana Alokasi Khusus (DAK) dalam undangundang nomor 27 tahun 2014 adalah dana yang bersumber dari pendapatan APBN yang dialokasikan dengan tujuan pemerataan kemampuan keuangan antara daerah untuk mendanai kebutuhan daerah dalam rangka pelaksanaan desentralisasi. Undangundang No. 27 Tahun 2014 tentang anggaran pendapatan dan belanja pemerintah menjelaskan bahwa pemerintah menetapkan tiga kriteria dalam penentuan DAK, yaitu kriteria umum, kriteria khusus dan kriteria teknis. Kriteria umum ditetapkan dengan mempertimbangkan kemampuan keuangan daerah dalam APBD.
Kriteria Umum $=$ Pendapatan Umum APBD -

Belanja Pegawai Daerah

Kriteria khusus dan kriteria teknis diatur dalam PP No. 55 tahun 2015. Dalam penelitian Hendriwijanto (2013) variabel ini diukur dengan presentasi DAK terhadap total pendapatan daerah ditulis dalam rumus rasio:

$\mathrm{DAK}=\frac{\text { Dana Alokasi Khusus }(\mathrm{DAK})}{\text { Total PenerimaanDaerah }} \times 100 \% \ldots . . .(5)$

Undang-Undang Nomor 27 Tahun 2014 pasal 1 ayat 16 disebutkan bahwa Dana Bagi Hasil (DBH) adalah dana yang bersumber dari pendapatan negara yang dialokasikan kepada daerah berdasarkan angka persentase tertentu untuk mendanai kebutuhan daerah dalam rangka pelaksanaan desentralisasi. Dalam Undang-Undang No. 21 Tahun 2001 tentang otonomi khusus, bagi Provinsi Papua mendapat porsi pendapatan revenue sharing sumber daya alam minyak bumi, gas bumi dan mineral sebesar $70 \%$ dari total pendapatan sumber daya alam yang diperoleh dari wilayah Papua sedangkan untuk pajak PBB sebesar 90\%. Yang dapat dirumuskan :

DBH Papua $=($ Total Pendapatan PBB x 90\% $)+$ (bea perolehan tanah dan bangunan $\mathrm{x} 80 \%$ ) + (hasil sumber daya alam $\mathrm{x}$ $55 \%)+($ hasil sumber daya mineral $\mathrm{x} 70 \%)+($ hasil minyak bumi dan gas alam x 40\%)

Dana otonomi khusus adalah dana perimbangan yang diberikan kepada daerah dalam rangka pelaksanaan otonomi khusus yang merupakan salah satu bentuk desentralisasi asimetri yang bertujuan mempercepat peningkatan kesejahteraan masyarakat dan pelayanan publik. Besaran dana otonomi khusus (DOK) diatur dalam UU Nomor 21 tahun 2001 tentang otonomi khusus Papua pada pasal 34 adalah sebesar 2\% dari dana alokasi umum (DAU) nasional. (Sumarjoko, 2014). Untuk pengolahan data dalam penelitian statistik ukuran rasio DOK dihitung dengan:

DOK $=\frac{\text { Dana Otonomi Khusus }(\mathrm{DOK})}{\text { Total PenerimaanDaerah }} \times 100 \%$...(7)

PSAP Nomor 2, Belanja Modal adalah pengeluaran anggaran untuk perolehan asset tetap dan asset lainnya yang memberi manfaat lebih dari satu periode akuntansi. Selanjutnya pada pasal 53 ayat 2 Per mendagri Nomor 59 Tahun 2007 ditentukan bahwa nilai asset tetap berwujud yang dianggarkan dalam belanja modal sebesar harga beli/ bangun asset ditambah seluruh belanja yang terkait 
dengan pengadaan/pembangunan asset sampai asset tersebut siap digunakan, nilai besaran belanja modal ini disajikan pada pos belanja pemerintah daerah dalam realisasi APBD, Dalam penelitian Adiputra dkk. (2015) dan Hendriwijanto (2013) komponen dari indikator belanja modal terdiri atas 1) Belanja peralatan dan mesin, 2) gedung dan tanah, 3)Belanja jalan, irigasi dan jaringan. Dalam pengolahan data komponen belanja modal akan di ukur dalam rasio :

$\underset{\text { Modal }}{\text { Rasio Belanja }}=\frac{\text { Komponen Belanja Modal }}{\text { Total Belanja Modal }} \times 100 \% \ldots(8)$

Konstruks Endogenus (Dependen) Pertumbuhan Ekonomi. Domestik Regional Bruto per Kapita (PDRB) adalah Pertumbuhan ekonomi adalah suatu proses kenaikan pendapatan total dan pendapatan per kapita dengan memperhitungkan adanya pertambahan penduduk dan disertai dengan perubahan fundamental dalam struktur ekonomi suatu wilayah dan pemerataan pendapatan bagi penduduk suatu wilayah (Situngkir, 2009).

Indek Harga Konsumen (IHK) adalah indeks yang mengukur harga rata-rata dari barang dan jasa yang dikonsumsi oleh rumah tangga (household). IHK sering digunakan untuk mengukur tingkat inflasi suatu negara dan juga sebagai pertimbangan untuk penyesuaian gaji, upah, uang pensiun, dan kontrak lainnya sehubungan dengan indikator pertumbuhan ekonomi seperti dalam penelitian Gatra (2005) yang di ukur dengan :

Pertumbuhan $\frac{\text { PDRB }_{t}-\text { PDRB- }_{t}}{\text { PDRB }_{t}}$ Ekonomi $=\frac{\mathrm{t}-\mathrm{PDR}_{\mathrm{t}}}{\mathrm{PDR}_{\mathrm{t}}} \times 100 \%$

Proses kenaikan output per kapita di proksi dengan Produk Domestik Regional Bruto per Kapita (PDRB) yang didefinisikan sebagai jumlah nilai tambah yang dihasilkan oleh seluruh unit usaha dalam suatu wilayah, atau merupakan jumlah seluruh nilai barang dan jasa akhir yang dihasilkan oleh seluruh unit ekonomi di suatu daerah Pertumbuhan ekonomi seperti dalam penelitian Hendriwijanto (2013) dan Sumardjoko (2014) diukur dengan :

$\mathrm{IHK}=(\mathrm{Pn} / \mathrm{Po})$ (10)

Keterangan :

$\mathrm{Pn}=$ Harga sekarang

Po $=$ Harga pada tahun dasar

Penelitian ini menggunakan metode analisis data dengan Structural Equation Modeling menggunakan Software SmartPLS, dalam penelitian ini, model struktural yang dianalisis merupakan model reflektif dengan semua indikator dari variabel eksogen yakni: Pendapatan Daerah, variabel mediasi Belanja Modal dan variabel Pertumbuhan Ekonomi,

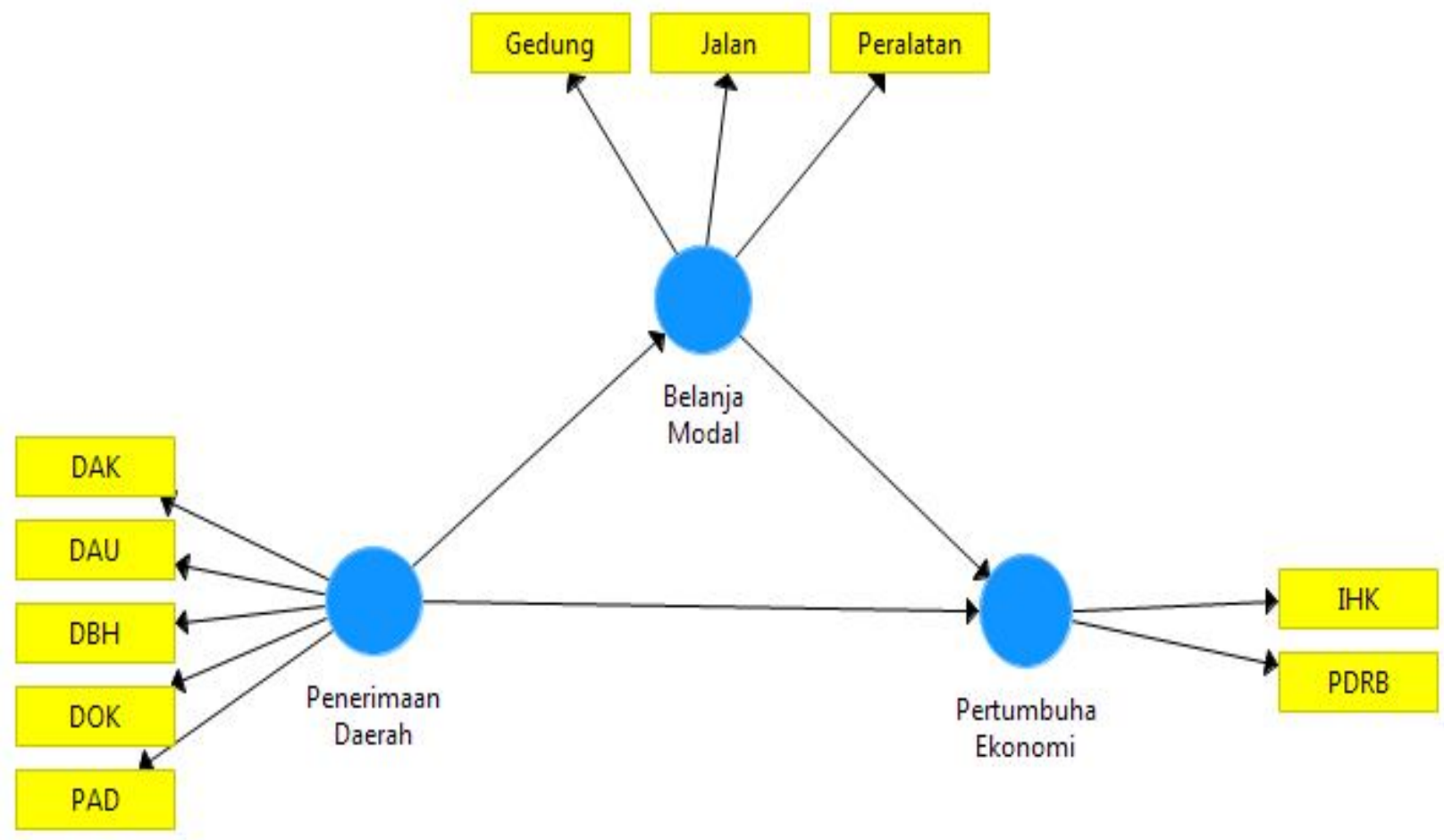

Sumber: Data diolah, 2016

Gambar 1. Model Penelitian 
Model analisis struktural yang dibangun dalam penelitian ini dapat dilihat pada gambar.

Evaluasi pengukuran atau outler model dilakukan untuk menilai validitas dan reliabilitas model. Outler model dengan indikator refleksif dievaluasi melalui convergent validitiy dan discriminate validitiy untuk indikator pembentuk konstruks laten, serta melalui composite reliability untuk blok indikatornya (Ghozali, 2011).

Convergent validitiy berhubungan dengan prinsip bahwa pengukur-pengukur (manifest variabel) dari suatu konstruks seharusnya berkorelasi tinggi. Uji convergent validitiy indikator refleksif dapat dilihat dari nilai loading factor untuk setiap konstruks, dimana nilai loading factor yang direkomendasikan harus lebih besar dari 0,70 untuk penelitian yang bersifat confirmatory. Validitas konvergen selain dapat dilihat melalui loading factor, juga dapat diketahui melalui Average Variance Extracted (AVE). Suatu instrumen dikatakan memenuhi pengujian validitas konvergen apabila memiliki Average Variance Extracted (AVE) diatas 0.50. (Ghozali, 2015).

Discriminate validitiy berhubungan dengan prinsip bahwa pengukur (manifest variabel) konstruks yang berbeda seharusnya tidak berkorelasi dengan tinggi. Discriminate validitiy dihitung menggunakan output cross loading factor dengan kriteria bahwa apabila nilai loading factor dalam suatu variabel yang bersesuaian lebih besar dari nilai korelasi indikator pada variabel lainnya maka indikator tersebut dinyatakan valid dalam mengukur variabel yang bersesuaian. Cara lain yang dapat digunakan untuk menguji validitas discriminant adalah dengan membandingkan akar kuadrat dari AVE untuk setiap konstruks dengan nilai korelasi antar konstruks dalam model. Discriminate validitiy yang baik ditunjukkan dari akar kuadrat AVE untuk setiap konstruks lebih besar dari korelasi antar konstruks dalam model (Ghozali, 2011).

Composite reliability digunakan untuk menguji realiabilitas konstruks yang diukur dengan dua kriteria yaitu composite reliability dan crombach alpha dari blok indikator yang megukur konstruks. Kriteria pengujian menyatakan bahwa apabila composite reliability bernilai lebih besar dari 0,70 dan cronbach alpha bernilai lebih besar dari 0,60 maka konstruks tersebut dinyatakan reliabel.

Pengujian terhadap model struktural dilakukan dengan melihat nilai R-Square yang di tunjukan oleh uji Goodness of fit Model, pengujian ini digunakan untuk mengetahui besarnya kemampuan variabel endogen untuk menjelaskan keragaman variabel eksogen, atau dengan kata lain untuk mengetahui besarnya kontribusi variabel eksogen terhadap variabel endogen. Goodness of fit Model dalam analisis PLS dilakukan dengan menggunakan $Q$ Square predictive relevance $\left(Q^{2}\right)$.

Hipotesis yang dirumuskan dalam penelitian ini diterima melalui pengujian signifikansi yang digunakan untuk menguji ada tidaknya pengaruh variabel eksogen terhadap variabel endogen melalui boostsraping. Kriteria pengujian menyatakan bahwa apabila koefisien bertanda positif dan nilai $t$ statistics $\varepsilon$ " $t$-value maka dinyatakan adanya pengaruh positif dan signifikan variabel eksogen terhadap variabel endogen. Nilai signifikansi yang digunakan dalam (2015) $t$-value 1,65 (significance level $=10$ persen), 1,96 (significance level $=5$ persen), dan 2,58 (significance level $=1$ persen (Thelen, 2012).

Pengujian hipotesis mediasi pada pengujian belanja modal sebagai variabel pe mediasi pengaruh antara pendapatan daerah dan pertumbuhan ekonomi melalui pengujian hipotesis indirect effect, dilakukan dengan tujuan untuk menguji ada tidaknya pengaruh secara tidak langsung variabel bebas terhadap variabel terikat melalui variabel mediasi nya. Dengan cara melakukan estimasi indirect effect secara simultan dengan SEM PLS yaitu pendapatan daerah terhadap pertumbuhan ekonomi, pendapatan daerah terhadap belanja modal, dan belanja modal terhadap Pertumbuhan Ekonomi.

Prosedur pengujian yang harus dipenuhi adalah model satu, menguji variabel eksogen (X) terhadap variabel endogen $(\mathrm{Y})$ dan dalam pengujian model ini harus signifikan. Model kedua, menguji pengaruh varibel eksogen $(\mathrm{X})$ terhadap varibel mediasi $(\mathrm{M})$ dan dalam pengujian model ini harus signifikan. Model ketiga, menguji secara simultan pengaruh variabel eksogen (X) dan mediasi (M) terhadap variabel endogen $(\mathrm{Y})$.

\section{HASIL DAN PEMBAHASAN}

Tiga kriteria pengukuran digunakan dalam teknik analisis data menggunakan Smart PLS untuk menilai model reflektif. Tiga pengukuran itu adalah convergent validity, composite reability dan discriminant validity.

Evaluasi validitas dilakukan dengan menghitung convergent validity, diketahui melalui loading factor. Suatu instrument dikatakan memenuhi pengujian validitas konvergen apabila memiliki loading factor diatas 0,70 hasil pengujian convergent validity disajikan dalam Tabel 1 
Tabel 1.

Hasil Uji Outer Loading

\begin{tabular}{|c|c|c|c|c|}
\hline Indikator & $\begin{array}{c}\text { Original } \\
\text { Sample } \\
(\mathrm{O})\end{array}$ & $\begin{array}{l}\text { Standard } \\
\text { Error } \\
\text { (STERR) }\end{array}$ & $\begin{array}{l}\text { T Statistics } \\
(|\mathrm{O} / \mathrm{STERR}|)\end{array}$ & Keterangan \\
\hline PAD $\leftarrow$ Pendapatan Daerah & 0,910 & 0,015 & 61,262 & valid \\
\hline $\mathrm{DBH} \leftarrow$ Pendapatan Daerah & 0,899 & 0,025 & 31,238 & valid \\
\hline DAU $\leftarrow$ Pendapatan Daerah & 0,585 & 0,034 & 10,356 & tidak valid \\
\hline DAK $\leftarrow$ Pendapatan Daerah & 0,717 & 0,083 & 8,137 & valid \\
\hline DOK $\leftarrow$ Pendapatan Daerah & 0,152 & 0,003 & 1,153 & tidak valid \\
\hline Peralata $\leftarrow$ Pendapatan Daerah & 0,973 & 0,004 & 344,773 & valid \\
\hline Gedung $\leftarrow$ Pendapatan Daerah & 0,981 & 0,003 & 364,001 & valid \\
\hline Jalan $\leftarrow$ Pendapatan Daerah & 0,983 & 0,004 & 257,344 & valid \\
\hline $\mathrm{PDRB} \leftarrow$ Pendapatan Daerah & 0,946 & 0,011 & 83,604 & valid \\
\hline IHK $\leftarrow$ Pendapatan Daerah & 0,943 & 0,010 & 87,386 & valid \\
\hline
\end{tabular}

Sumber: Data Diolah, (2016)

menunjukkan PAD, DHB, DAK memiliki nilai loading factor diatas 0,0 masing-masing untuk PAD 0,910, untuk DBH 0,899, untuk DAK 0.717 sedangkan DAU dan DOK memiliki loading factor kurang 0.70 yaitu DAU sebesar 0,685 dan DOK sebesar 0.152 sehingga perlu dilakukan atau drop dari analisa dan selanjutnya dilakukan uji kembali dengan menghilangkan indikator DAU dan DOK dengan hasil pada Tabel 2.
Indikator DAU dan DOK di keluarkan dan dil akuan uji kembali nampak pada Tabel 2 menunjukkan PAD, DHB, DAK memiliki nilai loading factor diatas 0,70 masing-masing $0,900,0,887,0,736$ sehingga semua indikator valid untuk mengukur konstruks pendapatan Daerah. Hasil pengujian convergent validity pada konstruks belanja modal menunjukkan Peralatan, Gedung, Jalan memiliki nilai loading factor diatas 0.70 masing-masing 0,973, 0,91, 0,983 sehingga semua indikator valid untuk

Tabel 2.

Hasil Uji Outer Loading (drop indikator DAK dan DOK)

\begin{tabular}{|c|c|c|c|c|}
\hline Indikator & $\begin{array}{c}\text { Original } \\
\text { Sample (O) }\end{array}$ & $\begin{array}{l}\text { Standard } \\
\text { Error } \\
\text { (STERR) }\end{array}$ & $\begin{array}{l}\text { T Statistics } \\
\text { (|O/STERR } \mid)\end{array}$ & Ket. \\
\hline PAD $\leftarrow$ Pendapatan Daerah & 0,900 & 0,015 & 60,117 & valid \\
\hline $\mathrm{DBH} \leftarrow$ Pendapatan Daerah & 0,887 & 0,025 & 35,496 & valid \\
\hline DAK $\leftarrow$ Pendapatan Daerah & 0,736 & 0,089 & 8,892 & valid \\
\hline Peralata $\leftarrow$ Pendapatan Daerah & 0,973 & 0,004 & 344,773 & valid \\
\hline Gedung $\longleftarrow$ Pendapatan Daerah & 0,981 & 0,003 & 364,001 & valid \\
\hline JalanŁPendapatan Daerah & 0,983 & 0,004 & 257,344 & valid \\
\hline $\mathrm{PDRB} \leftarrow$ Pendapatan Daerah & 0,946 & 0,011 & 83,604 & valid \\
\hline IHK $\leftarrow$ Pendapatan Daerah & 0,943 & 0,010 & 87,386 & valid \\
\hline
\end{tabular}

Sumber: Data Diolah, (2016)

mengukur konstruks belanja modal. Hasil pengujian convergent validity pada konstruks Pertumbuhan Ekonomi menunjukkan IHK, PDRB memiliki nilai loading factor diatas 0,70 masing-masing 0,973, $0.91,0,983$ sehingga semua indikator valid untuk mengukur konstruks belanja modal.

Validitas konvergen selain dapat dilihat melalui loading factor, juga dapat diketahui melalui Average Variance Extracted (AVE). Suatu instrumen dikatakan memenuhi pengujian validitas konvergen apabila memiliki Average Variance Extracted (AVE) diatas 0,50. Hasil pengujian validitas konvergen disajikan pada Tabel 3.

Tabel 3 menunjukan hasil Validitas Diskriminan yang menunjukkan nilai akar kuadrat AVE setiap konstruks lebih besar daripada nilai korelasi antara konstruks dengan konstruks lainnya dalam model. Hasil Validitas Diskriminan $\sqrt{\text { AVE }}$ konstruks 
Tabel 3.

Hasil Uji Validitas Diskriminan

\begin{tabular}{lll}
\hline \multicolumn{1}{c}{ Indikator } & AVE & $\sqrt{\text { AVE }}$ \\
\hline Belanja Modal & 0,959 & 0,979 \\
Pendapatan Daerah & 0,848 & 0,921 \\
Pertumbuhan Ekonomi & 0,892 & 0,944 \\
\hline
\end{tabular}

Sumber: Data Diolah, (2016)

pertumbuhan ekonomi sebesar 0,944 lebih tinggi daripada korelasi antara pertumbuhan ekonomi dengan konstruks lainnya dalam model yang sebesar 0,934 dan 0,849 , konstruks variabel selanjutnya yaitu Pendapatan Daerah sebesar 0,921 lebih tinggi dari pada korelasi antara konstruks Pendapatan Daerah dengan konstruks lainnya dalam model sebesar 0,858 dan 0,849 , selanjutnya konstruks belanja modal sebesar 0,979 lebih tinggi dari pada korelasi antara konstruks belanja modal dengan konstruks lainnya dalam model yang hanya sebesar 0,858 dan 0,934.

Validitas Diskriminan dihitung menggunakan output cross loading factor dengan kriteria bahwa apabila nilai loading factor dalam suatu variabel

Tabel 4.

Hasil Uji Cross Loading Factor

\begin{tabular}{cccc}
\hline Indikator & Pendapatan Daerah & Belanja Modal & $\begin{array}{c}\text { Pertumbuhan } \\
\text { Ekonomi }\end{array}$ \\
\hline DAK & 0,738 & 0,555 & 0,520 \\
DBH & 0,887 & 0,626 & 0,664 \\
PAD & 0,900 & 0,863 & 0,864 \\
Gedung & 0,858 & 0,981 & 0,938 \\
Jalan & 0,877 & 0,983 & 0,922 \\
Peralatan & 0,786 & 0,973 & 0,874 \\
PDRB & 0,873 & 0,879 & 0,946 \\
IHK & 0,731 & 0,887 & 0,943 \\
\hline
\end{tabular}

Sumber: Data Diolah, (2016)

yang bersesuaian lebih besar dari nilai korelasi indikator pada variabel lainnya maka indikator tersebut dinyatakan valid dalam mengukur variabel yang bersesuaian.

Berdasarkan pengukuran cross loading factor pada Tabel 4, dapat diketahui bahwa secara keseluruhan indikator-indikator dari variabel pendapatan Daerah, belanja modal, dan pertumbuhan ekonomi menghasilkan cross loadin yang lebih besar dibandingkan dengan output cross loadin pada variabel lainnya. Dengan demikian dapat dinyatakan bahwa masing-masing indikator mampu mengukur variabel laten yang bersesuaian dengan indikatornya.

Hasil perhitungan composite reliability dan cronbach alpha dapat dilihat melalui ringkasan yang disajikan dalam Tabel 5.

Tabel 5.

Hasil Uji Reliabilitas

\begin{tabular}{lcc}
\hline \multicolumn{1}{c}{ Variabel } & Composite Reliability & Cronbachs Alpha \\
\hline Belanja Modal & 0,986 & 0,979 \\
Pendapatan Daerah & 0,878 & 0,813 \\
Pertumbuhan Ekonomi & 0,943 & 0,879 \\
\hline
\end{tabular}

Sumber: Data Diolah, (2016)

Berdasarkan tabel 5 dapat diketahui bahwa nilai composite reliability pada variabel pendapatan Daerah, belanja modal, dan pertumbuhan ekonomi lebih besar dari 0.70. Dengan demikian, berdasarkan perhitungan composite reliability semua indikator yang mengukur variabel pendapatan Daerah, belanja modal, dan pertumbuhan ekonomi dinyatakan reliabel. Nilai Cronbach's Alphapada variabel 
pendapatan Daerah, belanja modal, dan pertumbuhan ekonomi lebih besar dari 0,60. Dengan demikian, berdasarkan perhitungan Cronbach's Alpha semua indikator yang mengukur variabel pendapatan Daerah, belanja modal, dan pertumbuhan ekonomi dinyatakan reliabel.

Pengujian terhadap model struktural dilakukan dengan melihat nilai R-Square yang di tunjukan oleh uji Goodness of fit Model dalam analisis PLS dilakukan dengan menggunakan $Q$-Square predictive relevance $\left(Q^{2}\right)$. Adapun hasil Goodness of fit Model yang telah diringkas dalam Tabel 6.

\section{Tabel 6.} Hasil Uji Model

\begin{tabular}{lc}
\hline \multicolumn{1}{c}{ Variabel } & $R^{2}$ \\
\hline Belanja Modal & 0,355 \\
Pertumbuhan Ekonomi & 0,418 \\
$\mathrm{Q}^{2}$ & 0,625 \\
\hline Sum
\end{tabular}

Sumber: Data Diolah, (2016)

$R$-square variabel belanja modal bernilai 0,355 atau 35,5 persen Hal ini dapat menunjukkan bahwa keragaman variabel belanja modal dijelaskan oleh variabel pendapatan Daerah sebesar 35,5 persen, atau dengan kata lain kontribusi variabel pendapatan Daerah terhadap variabel belanja modal sebesar 35,5 persen, sedangkan sisanya sebesar 64,5 persen merupakan kontribusi variabel lain yang tidak dibahas dalam penelitian ini. Selanjutnya R-square variabel pertumbuhan ekonomi bernilai 0,418 atau 41,8 persen. Hal ini dapat menunjukkan bahwa keragaman variabel pertumbuhan ekonomi mampu dijelaskan oleh variabel pendapatan Daerah dan belanja modal sebesar 41,8 persen, atau dengan kata lain kontribusi variabel pendapatan Daerah dan belanja modal terhadap variabel pertumbuhan ekonomi sebesar 41,8 persen, sedangkan sisanya sebesar 58,2 persen merupakan kontribusi variabel lain yang tidak dibahas dalam penelitian ini. $Q$-Square predictive relevance $\left(Q^{2}\right)$ bernilai 0,625 atau 62,5 persen. Hal ini dapat menunjukkan bahwa keragaman variabel pertumbuhan ekonomi mampu dijelaskan oleh model secara keseluruhan sebesar 62,5 persen, atau dengan kata lain kontribusi pendapatan Daerah dan belanja modal terhadap variabel pertumbuhan ekonomi secara keseluruhan sebesar 62,5 persen, sedangkan sisanya sebesar 37,5 persen merupakan kontribusi variabel lain yang tidak dibahas dalam penelitian ini.

Kriteria pengujian menyatakan bahwa apabila koefisien bertanda positif dan nilai $t$-statistics e" $t$ value $(1,96)$ maka dinyatakan adanya pengaruh positif dan signifikan variabel eksogen terhadap variabel endogen. (ghozali, 2015). Hasil pengujian signifikansi dapat diketahui melalui Tabel 7.

Tabel 7.

Hasil Uji Path Coefficients

\begin{tabular}{lccc}
\hline \multicolumn{1}{c}{ Variabel } & $\begin{array}{c}\text { Original } \\
\text { Sample }(\mathrm{O})\end{array}$ & $\begin{array}{c}\text { Standard } \\
\text { Error } \\
(\text { STERR })\end{array}$ & $\begin{array}{c}\text { T Statistics } \\
(\mid \text { O/STERR } \mid)\end{array}$ \\
\hline Pendapatan Daerah $\rightarrow$ PertumbuhanEkonomi & 0,179 & 0,067 & 2,667 \\
Pendapatan Daerah $\rightarrow$ Belanja Modal & 0,859 & 0,017 & 49,339 \\
Belanja Modal $\rightarrow$ PertumbuhanEkonomi & 0,781 & 0,063 & 12,437 \\
\hline
\end{tabular}

*tingkat signifikansi 5\%

Sumber : Data Diolah (2016)

Hasil pengolahan data menujukan pendapatan daerah berpengaruh positif dan signifikan terhadap pertumbuhan ekonomi dengan koefisien jalur sebesar 0,179 dengan nilai $t$-statistic 2,667 yang artinya semakin tinggi pendapatan daerah maka pertumbuhan ekonomi semakin naik.

Kenaikan pendapatan daerah maka akan berdampak pada peningkatan capaian pertumbuhan ekonomi yang positif, karena pendapatan daerah sebagai penggerak dari aktivitas operasional pemerintah, akan mampu meningkatkan pelayanan publik melalui penyediaan sarana dan prasarana yang baik, sehingga mampu menunjang aktivitas masyarakat serta berkontribusi pada pertumbuhan ekonomi di daerah tersebut. Perlu mendapat perhatikan ketika alokasi pendapatan daerah yang di gunakan untuk program yang bersifat produktif dan bersentuhan langsung dengan kepentingan publik akan dapat menjadi stimulus perekonomian. Misalnya, pembangunan infrastruktur akan mendorong investasi, dengan adanya investasi ekonomi akan berkembang dan menciptakan lapangan kerja baru sehingga akan menyerap pengangguran dan memperkecil kemiskinan dan pada akhirnya akan meningkatkan pendapatan per kapita dan mendorong pertumbuhan ekonomi rill. 
Hasil annalisa menujukan pendapatan Daerah berpengaruh positif dan signifikan terhadap belanja modal dengan koefisien jalur sebesar 0,559 dengan nilai T statistik 49,339, yang artinya semakin tinggi pendapatan daerah maka akan semakin bertambah pula alokasi belanja modal.

Penelitian ini menujukan pendapatan daerah di Papua yang meningkat, berdampak pada menambah alokasi belanja modal yang digunakan untuk pembangun berbagai infrastruktur, pendapatan daerah sebagai pendapatan kas daerah, merupakan sarana pemerintah daerah untuk menjalankan kegiatan operasional, memberikan pelayanan publik dan melakukan pembangunan di daerah dengan tujuan untuk meningkatkan kesejahteraan masyarakat di segala bidang kehidupan, pendapatan daerah merupakan pendapatan yang sangat penting bagi pemerintah daerah dalam menunjang pembangunan daerah guna membiayai proyek-proyek dan infrastruktur daerah, jika dialokasikan pada belanja model dengan baik. Mengingat infrastruktur memegang peranan penting sebagai salah satu roda penggerak pertumbuhan ekonomi dan pembangunan sektor ini menjadi fundamental bagi pertumbuhan ekonomi selanjutnya.

Hasil pengujian data menunjukan belanja modal berpengaruh positif terhadap pertumbuhan ekonomi dengan koefisien jalur sebesar 0,781 dengan nilai $t$ statistik 12,437 artinya semakin besar belanja modal akan mendorong semakin tinggi pertumbuhan ekonomi.

Besarnya dana yang dialokasikan pada belanja modal untuk membangun infrastruktur memegang peranan penting sebagai salah satu roda penggerak pertumbuhan ekonomi, karena terbukti besaran alokasi belanja modal berpengaruh terhadap pertumbuhan ekonomi di Papua, artinya bahwa penambahan belanja modal untuk pengadaan infrastruktur yang baik serta memadai sangat diperlukan untuk menopang pertumbuhan ekonomi yang lebih tinggi, lebih merata dan lebih menyejahterakan masyarakat, program peningkatan belanja modal mau tidak mau akan menyentuh langsung, peningkatan pembangunan daerah.

Belanja yang bersifat produktif dan bersentuhan langsung dengan kepentingan publik akan dapat menjadi stimulus perekonomian. Misalnya, jalan tras Papua dan bandara perintis yang dibangun saat ini di Papua terbukti mampu mengerakkan ekonomi masyarakat karena pembangunan infrastruktur akan mendorong investasi, dengan adanya investasi ekonomi akan berkembang dan menciptakan lapangan kerja baru sehingga akan menyerap pengangguran dan memperkecil kemiskinan dan pada akhirnya akan meningkatkan pendapatan per kapita dan mendorong pertumbuhan ekonomi rill.

Hasil pengolahan data menujukan pendapatan daerah berpengaruh terhadap pertumbuhan ekonomi melalui belanja modal dengan hasil pengujian koefisien direct effect sebesar 0,653 dan indirect effect 0,176 keduanya signifikansi hal ini menujukan bentuk mediasi parsial artinya kenaikan pendapatan daerah tidak serta merta meningkatkan pertumbuhan ekonomi tanpa diikuti belanja modal yang efektif dan efisien dalam bentuk kegiatan-kegiatan produktif yang mengarahkan pada pembanguan ekonomi meskipun mediasi tersebut adalah partial mediasi sehingga belanja modal bukan satu-satunya pemediasi pengaruh pendapatan daerah terhadap pertumbuhan ekonomi di Papua.

Pengelolaan alokasi anggaran pemerintah yang baik, melalui belanja-belanja pemerintah yang produktif akan mampu meningkatkan aktivitas ekonomi di daerah, karena pertumbuhan ekonomi terwujud dengan cara meningkatkan dan menciptakan aktivitas ekonomi baru dalam masyarakat, sehingga secara makro terjadi peningkatan jumlah output barang dan jasa pada daerah yang bersangkutan yang diikuti pula dengan meningkatnya jumlah uang beredar dari segi pembelanjaan yang dilakukan oleh pemerintah daerah. (Ranis, 2000). Pembangunan berbagai infrastruktur seperti jalan, jembatan akan mampu mempercepat mobilisasi orang dan barang ke berbagi tempat sehingga mampu mengerikan aktivitas ekonomi masyarakat dengan baik di daerah.

Untuk mengetahui pengaruh pendapatan daerah terhadap pertumbuhan ekonomi dengan medias belanja modal maka dilakukan pengujian hipotesis indirect effect dengan tujuan untuk menguji ada tidaknya pengaruh secara tidak langsung variabel bebas terhadap variabel terikat melalui variabel mediasinya nya.

Hasil pengujian menujukkan bahwa koefisien direct effect pada model satu pendapatan daerah terhadap pertumbuhan ekonomi secara langsung atau tampa mediasi dengan koefisien jalur sebesar 0.653 bernilai positif dengan nilai $\mathrm{T}$ statistics sebesar 10.234 atau nilai $t$-statistics $>1,96$ memiliki pengaruh signifikan sehingga syarat model satu, pengujian variabel eksogen $(\mathrm{X})$ terhadap variabel endogen $(\mathrm{Y})$ dan dalam pengujian model ini harus signifikan telah terpenuhi. Pada model kedua pendapatan daerah terhadap belanja modal secara langsung menghasilkan koefisien jalur sebesar 0.762 bernilai positif dengan nilai $\mathrm{T}$ statistics sebesar 23.912 atau 
Tabel 8.

Hasil Uji Path Coefficients

\begin{tabular}{lcccc}
\hline \multicolumn{1}{c}{ Variabel } & \multicolumn{4}{c}{ Coefficients } \\
& Direct & $\begin{array}{c}\text { T Statistics } \\
(\mid \text { O/STER })\end{array}$ & Indirect & $\begin{array}{r}\text { T Statistics } \\
(\mid \text { O/STER })\end{array}$ \\
\hline $\begin{array}{l}\text { Model 1 } \\
\text { Pendapatan Daerah } \rightarrow \text { Pertumbuhan Ekonomi }\end{array}$ & 0,653 & 10,234 & & \\
Model 2 & & & & \\
Pendapatan Daerah $\rightarrow$ Belanja Modal & 0,762 & 23,912 & & \\
Model 3 & & & & \\
Pendapatan Daerah $\rightarrow$ Belanja Modal & & & 0,859 & 49,339 \\
Pendapatan Daerah $\rightarrow$ Pertumbuhan Ekonomi & & & 0,179 & 2,667 \\
Belanja Modal $\rightarrow$ Pertumbuhan Ekonomi & & & 0,781 & 12,437 \\
\hline
\end{tabular}

Sumber : Data Diolah (2016)

nilai $t$-statistics $>1,96$ memiliki pengaruh signifikan sehingga syarat model kedua menguji pengaruh varibel eksogen $(\mathrm{X})$ terhadap varibel mediasi $(\mathrm{M})$ dan dalam pengujian model ini harus signifikan telah terpenuhi, selanjutnya model ketiga hasil pengujian estimasi pada model dengan mediasi belanja menujukan nilai yang dihassilkan indirect effect pendapatan daerah terhadap pertumbuhan ekonomi turun ketika di masukan variabel belanja modal (dari 0.653 direct effect) menjadi 0.176 namun tetap signifikan. Hal ini menujukkan bentuk partial mediation atau mediasi sebagian dengan kata lain belanja modal memediasi secara parsial pengaruh pendapatan daerah terhadap pertumbuhan ekonomi. Bentuk partial mediation ini berarti belanja modal bukan satu-satunya pemediasi pengaruh pendapatan daerah terhadap pertumbuhan ekonomi di Papua. Sehingga $\mathrm{H}_{4}$ hipotesis indirect effect diterima bahwa pendapatan daerah berpengaruh terhadap pertumbuhan ekonomi melalui belanja modal dalam bentuk pemediasi parsial.

\section{SIMPULAN}

Hasil analisis menyimpulkan bahwa pendapatan daerah berpengaruh positif dan signifikan terhadap pertumbuhan ekonomi, sehingga semakin tinggi pendapatan daerah maka pertumbuhan ekonomi akan semakin naik. Pendapatan berpengaruh positif dan signifikan terhadap belanja modal hal ini menujukan bahwa semakin tinggi pendapatan akan menambah alokasi anggaran belanja modal. Belanja modal berpengaruh positif dan signifikan terhadap pertumbuhan ekonomi artinya semakin besar belanja modal akan mendorong semakin tinggi pertumbuhan ekonomi. Hasil uji mediasi menujukan belanja modal mampu memediasi pendapatan daerah terhadap pertumbuhan ekonomi dalam bentuk partial mediation atau mediasi sebagian yang artinya dengan kata lain belanja modal memediasi secara parsial pengaruh pendapatan daerah terhadap pertumbuhan ekonomi.

Analisis tersebut memiliki implikasi diantaranya terhadap kebijakan pengelolaan anggaran bagi pemerintah daerah. Pengalokasian pendapatan daerah terutama untuk belanja daerah, agar mempertimbangkan komponen belanja yang dianggap mampu untuk mendorong perekonomian daerah atau yang secara langsung, bersinggungan dengan kegiatan ekonomi masyarakat, sehingga mampu menunjang produktivitas dan mobilisasi masyarakat di daerah. Penelitian ini menggunakan belanja modal sebagai mediasi terhadap pendapatan daerah terhadap pertumbuhan ekonomi, yang menunjukan belanja modal mampu mediasi pendapatan daerah terhadap pertumbuhan ekonomi secara partial mediation, hal ini mungkin akan berbeda jika dilakukan pada daerah lain yang kondisi pemerintahan dan pertumbuhan ekonomi telah stabil atau daerah yang menerapkan otonomi secara umum.

\section{REFERENSI}

Adiputra, I.M.P, N.D. Dwiyantari, \& D.K. Darmada. (2015). Pengaruh PAD, Dana Perimbangan Dan SiLPA Terhadap Kualitas Pembagunan Manusia Dengan Alokasi Belanja Modal Sebagai Variabel Intervening. Simposium Nasional Akuntansi XVII Medan, 243-250.

Agustinus, J. (2013). Phenomoenology Study on Financial Performance and Management Accountability of Special Autonomy Funds Allocated for Education at the Province of 
Papua, Indonesia. Gajah Mada International Journal of Business, 15(1), 79-94.

Bahl, B. (1999). Implementation Rules For Decentralization. International Seminar On Land Policy And Economic Development. Londen, 2, 2-3.

Barro, R. J. (1991). Economic Growth In A Cross Section Of Countries. European Journal of Political Economy. 106(2), 407-442.

Dimang, A. (2011). Pengaruh Pendapatan Asli Daerah (PAD), Dana Alokasi Umum (DAU), Dana Alokasi Khusus (DAK) Terhadap Pertumbuhan Ekonomi dengan Belanja Modal Sebagai Variabel Intervening di Kabupaten dan Kota Provinsi Aceh. Tesis. Progam Pasca Sarjana Universitas Sumatera Utara. Medan.

Dunca, C.R. (2017). Mixed Outcomes: The Impact of Regional Autonomy and Decentralization on Indigenous Ethnic Minorities in Indonesia. Developement and Changel, 38(4), 711-733.

Dunca, C. R., (2017). Mixed Outcomes: The Impact of Regional Autonomy and Decentralization on Indigenous Ethnic Minorities in Indonesia. Developement and Change, (38) 4 : 711-733.

Firman, T. (2009). Decentralization Reform And Local-Government Proliferation In Indonesia: Towards A Fragmentation Of Regional Development Urban and regional. Development Studies, 21(2), 147-157.

Freddy. C, M.M. \& Matreria, S.B. Sitompul. (2013). Pengaruh Desentralisasi Fiskal Terhadap Pertumbuhan Ekonomi. Jurnal Setara Ekonomi Pembagunan, 5(2), 110-122.

Fjeldstad, O.H. (2001). Intergovernmental Fiscal Relations In Developing Countries. Areview of Issues, 34(3), 123-131.

Gunantara, I., \& I, Dwirandra. (2014). Dampak Desentralisai Fisakal Terhadap Pertumbuhan Ekonomi Kabupaten Simalungun. Tesis. Program Pascasarjana Universitas Sumatera Utara. Medan.

Ghozali, I. (2015). Aplikasi Analisis Multivariat dengan Program SPSS. Cetakan ke IV. Badan Penerbit Universitas Diponegoro. Semarang. (2011). Structural Equation Modeling Metode Alternatif Dengan Partial Least Square (PLS). Edisi tiga. Badan Penerbit Universitas Diponegoro. Semarang.

Hendriwiyanto, G. (2013). Pengaruh Pendapatan Daerah Terhadap Pertumbuhan Ekonomi Dengan Belanja Modal Sebagai Variabel Mediasi Pada Provinsi, Jurnal STIE Semarang, 6(1), 11-16.
Hagen, J.V. (2002). Fiscal Rules, Fiscal Institutions, And Fiscal Performen. The Economic and Social Review. 33(3), 263-284.

Jahasen, S. Juseliu. K., (1990). Maximum Likelihood Estimation And Inference On CointegrationWith Applications To The Demand For Money. Oxford Bulletin Of Economics and Statistics. 52(4), 169-210.

Kusnandar., D. Siswantoro. (2011). Pengaruh Dana Alokasi Umum, Pendapatan Asli Daerah, Sisa Lebih Pembiayaan Anggaran dan Luas Wilayah Terhadap Belanja Modal. Jurnal Administrasi Negara 2(2), 33-45.

Krueger, A.O. (1990). The Political Economy of the Rent-Seeking Society. The American Economic Review, 64(3), 291-303.

Kwo, O. 2003. The Effects of Fiscal Decentralization on Public Spending: The Korean Case. Public Budgeting \& Finance, 23(4), 1-20.

Laimeheriwa, M. H. D. (2013). Analisis Pengaruh Pendapatan Dan Dana Otonomi Khusus, Alokasi Umum, Dana Alokasi Khusus, Dana Bagi Hasil Terhadap Belanja Modal Dan Indeks Pembagunan Manusia (Studi Pada Kota/ Kabupatendi Provinsi Papua). Aset jurnal. 10(2), 11-18.

Landau, D. (1998). Government Expenditure and Economic Growth: A Cross-Country Study. Southerm Econoic Journal. 49(3),783-792.

Lee, Y. H. (2013). The Effects of Intergovernmental Trasnsfers For Urban Development In Korea. Public Budgeting \& Finance. 23(4).

Meilen, G.P., A. Naukoko, \& P. Wauran. (2014). Pengaruh Dana Alokasi Umum dan Belanja Langsung Terhadap Pertumbuhan Ekonomi dan Dampaknya Terhadap Kemiskinan di Kota Manado Tahun 2004-2012. Jurnal ekonomi dan keuangan, 14(3), 65-73.

McGibbon.R. (2004). Secessionist Challenges in Aceh and Papua: Is Special Autonomy the Solution?. Policy Studies Journal. 10, 101-104

Mudrajat, K. (2004). Otonomi Dan Pembagunan Daerah. Erlangga. Jakarta.

Ranis, G. (2000). Economi Growth and Humen Development. World Development Journal, 28(2), 197-219.

Situngkir, A. (2009). Pengaruh Pertumbuhan Ekonomi, Pendapatan Asli Daerah, Dana Alokasi Umum, Dan Alokai Khusus Terhadap Anggaran Belanja Modal Pada Pemko/Pemkab Sumatera 
Utara. Tesis. Universitas Sumatra Utara. Medan.

Sodik, J. (2007). Pengaruh Pendapatan Dan Pertumbuhan Ekonomi Regional (Studi Kasus Data Panel Di Indonesia). Jurnal Ekonomi Pembagunan PILAR, 4(1), 1-12.

Stine. W. F. (2003). Is Local Government Revenue Response Federal Aid Symetrical, Evidence From Pennsylvania Country Government in Era Retrenchment. National Tax Journal, 47(3), 338-342.

Sumardjoko, I. (2014). Pengaruh Pendapatan Dana Otonomi Khusus Terhadap Indek Pembagunan Manusia Papua Dan Papua Barat Dengan Belanja Modal Sebagi Intervening. Simposium Nasional Akuntansi XVII Mataram, 214-220.

Try, I. (2011). Pengaruh Pendapatan Asli Daerah (PAD) dan Dana Alokasi Umum (DAU) Terhadap Belanja Langsung (Studi Pada Pemerintah Daerah Kabupaten/Kota di Provinsi Jawa Tengah. Jurnal Akuntansi dan Auditing, 7(2), 1-9.

Thelen, M. Ellen. R. (2012). A Bootstrapping Medhod for Learning Semantic Lexicons
Using Extraction Pattern Contexts. EMNLP, 214-221.

Uhise, S. (2013). Dana Alokasi Umum (DAU) Pengaruhnya Terhadap Pertumbuhan Ekonomi Sulawesi Utara dengan Belanja Modal Sebagai Varibel Intervening. Jurnal EMBA, 11(4), 16771686.

Undang-Undang Republik Indonesia Nomor 17 Tahun 2000. Tentang Perubahan Ketiga Atas Undang-Undang Nomor 7 Tahun 1983 Tentang Pajak Penghasilan. Lembar Negara RI Tahun 2000. Sekertariat Negara. Jakarta.

Nomor 21 Tahun 2001. Otonomi Khusus Bagi Provinsi Papua. Lembar Negara RI Tahun 2001. Nomor 135. Sekertariat Negara. Jakarta. Nomor 32 Tahun 2004. Tentang Pemerintah Daerah. Lembar Negara RI Tahun 2004. Nomor 125. Sekertariat Negara. Jakarta.

Nomor 33 Tahun 2004. Tentang Perimbangan Keuangan Antara Pemerintah Pusat Dan Daerah. Lembar Negara RI Tahun 2004. Nomor 126. Sekertariat Negara. Jakarta. Wandira, G. Arbie. (2013). Pengaruh PAD, DAU, DAK, dan DBH Terhadap Pengalokasian Belanja Modal. Accounting Analysis Journal 33(1), 23-30. 